\title{
Analysis of the Factors Affecting Resistance to Changes in Management Accounting Systems
}

\section{Rodrigo Angonese}

Ph.D. Professor, School of Economic, Administrative and Accounting Sciences, University of Passo Fundo

E-mail: rangonese@gmail.com

Carlos Eduardo Facin Lavarda

Ph.D. Professor, Department of Accounting, Regional University of Blumenau

E-mail: clavarda@furb.br

Received on 02.21.2013 - Desk acceptance on 02.25.2013 - $4^{\text {th }}$ version accepted on 06.30.2014.

\begin{abstract}
Despite changes in the environment and management accounting practices, studies indicate that management accounting systems do not change or change at a much slower rate than expected. The stability of the management accounting systems used by companies may relate to resistance to changing these systems. This study analyzes the factors that contribute to resistance to implementing an integrated management system from the perspective of institutional theory, grounded in the old institutional economics. Methodologically, this study provides a qualitative assessment of the problem and a descriptive analysis of the resistance factors through a case-study approach. The data were collected using semi-structured interviews and analyzed through content analysis. Two companies were selected for this study due to their differing characteristics. The following seven factors were analyzed for resistance to implementing integrated management systems: institutional power, ontological insecurity, trust, inertia, lack of knowledge, acceptance of routines and decoupling. However, there was no evidence to characterize hierarchical power. The research findings indicate that changing management accounting systems, through the implementation of an integrated management system, faces internal resistance in these organizations. Each factor varies in intensity but is permanently present in these companies, such as ontological insecurity, trust, inertia, lack of knowledge, acceptance of routines and decoupling. These factors are awakened when the change process begins and, if they gather enough force, can stop the change.
\end{abstract}

Keywords: Resistance. Integrated management systems. Management accounting. Institutional theory. Change. 


\section{INTRODUCTION}

Understanding the factors that provoke resistance to changing management accounting systems can help explain why companies do not promote such changes to these systems (Granlund, 2001). Resistance to change may prevent the implementation of management accounting practices.

Since the 1980s, several management accounting practices have been developed. Other changes have been environmental, such as advances in information technology, technologies for managing organizations (e.g., Business Intelligence - BI, Enterprise Resource Planning Systems - ERPS, etc.), e-commerce, electronic data interchange, and market liberalization, and have changed the way companies conduct their activities. Despite such considerable changes, management accounting practices have changed little (Scapens, 1994).

This study addresses resistance to a particular change in management accounting systems: the implementation of Enterprise Resourcing Planning Systems (ERPS) in two companies. ERPSs are integrated information systems responsible for all information flows in an organization (Dechow, Granlund, \& Mouritsen, 2007). Management information systems use technology, such as systems and networks, to operationalize the information necessary to manage an organization (Otley, 1999; Dechow et al., 2007). Accounting is managed through a subset of the management information system that utilizes integrated management systems to generate and communicate information (Wagner, Moll, \& Newell, 2011). When the implementation of an ERPS includes the accounting module, as in the two companies selected for this study, changes to the accounting system occur. Therefore, the implementation of integrated management systems leads to changes in management accounting systems (Ferreira \& Otley, 1999; Scapens \& Jazayeri, 2003).

This study addresses this change process in two companies. One company completed the process (i.e., implemented ERPS), while the other company did not. Resistance to change cannot be understood as irrational (Scapens \& Roberts, 1993). Rather, resistance is a complex phenomenon (Busco, Quattrone, \& Riccaboni, 2007), which lacks studies that reveal its origins (Granlund, 2001).

This study uses institutional theory, based on the old institutional economics, to explain the factors that lead to resistance (Ribeiro \& Scapens, 2006). Institutional theory has been prominent in the growth of management accounting research and changes within management accounting that include the social and institutional dimensions of organizations and their environments (Moll, Burns, \& Major, 2006). Factors such as pressures arising from modes of thinking and circuits of trust and power are present in the change process (Scapens \& Roberts, 1993; Scapens, 2006; Busco, Riccaboni, \& Sca- pens, 2006) and in the socio-institutional environment in which organizations are embedded. Conceptualizing accounting as a socio-institutional practice facilitates understanding change in management accounting systems (Carruthers, 1995; Jeacle, 2003; Dambrin, Lambert, \& Sponem, 2007).

The general objective of this study is to analyze the factors affecting resistance to the implementation of an integrated management system from the perspective of institutional theory grounded in the old institutional economics. The hypothesis that guides this study is that changing the management accounting systems by implementing an integrated management system will face internal resistances in the organizations, and each resistance factor varies in intensity and is permanently present in the company.

This paper contributes to the literature by gathering the various factors affecting resistance to change identified in previous studies and determining whether these factors arise in two situations of changing management accounting systems. Studies often address resistance by highlighting a case and identifying, explicitly or not, one or more specific factors that explain resistance in that situation. In this study, resistance to change is perceived as complex and dependent on a set of resistance factors rather than factors that are specific to each case. These resistance factors manifest with different intensities early in the change process. Evidence is sought to confirm that resistance to change can be explained by factors that vary in intensity but are permanently present, even if in a latent state, in the company.

Practically, this study implies that implementing changes to management accounting systems in high-strain contexts characterized by resistance is undesirable because of the time and resources spent in these situations. Understanding how change occurs within management accounting is important for understanding the forces that drive change and for identifying the personal and institutional interests involved in the process. Making changes in the management accounting systems without care and without considering the organization socio-institutional environment will likely result in resistance to change (Scapens, 2006).

Thus, change in management accounting is an ongoing process rather than a single movement from one position to another, and there are conditions to successful implementation (Scapens, 2006). Successful change to the management accounting system should consider the perspectives of the various groups within the organization (Malmi, 1997). Thus, understanding of the phenomenon based on the proposed perspective will help organizations manage changes to their management accounting systems. Knowing the sources of possible resistance to change beforehand enables organizations to adopt strategies to mitigate that factor and significant increase the likelihood of successful change. 
This article is structured as follows: in section 2, the theoretical foundations of resistance to change are presented and the rationale for selecting the seven factors analyzed in this study is discussed. In section 3 , the methodological procedures are presented. Section 4 dis- cusses the proposed theme, including an analysis of the results of each case as well as an analysis and discussion of the resistance factors in the change process. Finally, in section 5, the conclusion and recommendations for future research are presented.

\section{DIMENSION OF THE FACTORS OF RESISTANCE TO CHANGE}

This section presents some of the factors identified in previous research as motivators of resistance to change in management accounting systems. The seven resistance factors that will be presented in sections 2.1-2.7 constitute the categories analyzed in this study. Because this study examines an explanatory case, previously identified resistance factors must be described (Scapens, 1990).

This study involved the definition of categories and subcategories for analysis, which were obtained by analyzing the theoretical framework. In addition to characterizing the factors affecting resistance to change, this section presents the logic that guided the development of the studied construct. The details are provided in Table 1.

\subsection{Institutional Power.}

Placing accounting in a broad social context reveals that, far from being a simple, neutral recording and measuring instrument, accounting involves power relationships (Napier, 2006). Power can exist anywhere in an organization and may be mobilized to resist to new organizational rules (Burns \& Scapens, 2000). Power may arise from the organization of individuals or groups within the organization itself. Burns and Scapens (2000) argue that when individuals or groups possess enough power through the control of the resources required to implement a change, they may be able to resist or undermine the change process.

Studies of management accounting (Weick, 1976; Bryman, 1984; Dermer \& Lucas, 1986) suggest that individuals and groups within organizations have different interests and goals and are engaged in a constant struggle to achieve them (Quattrone \& Hopper, 2001).

Power can be understood as a manifestation of an element, or a group of elements, within the organization, that protest proposed changes to management accounting (Burns \& Scapens, 2000). One way through which institutional power establishes itself is the autonomy of departments within the organization. This autonomy stems from the advantages of delegation of authority and responsibility to those departments, which are associated with benefits obtained from high performance and functionality (Scapens \& Roberts, 1993). The greater the authority and responsibility of a department that generates high performance and functionality, the greater the autonomy of that department and, consequently, the greater its power to resist changes to the management accounting system.

The resistance factor, institutional power, is affected by three subcategories: autonomy of departments, advantages of delegation and advantages of performance. Thus, it is expected that, excerpts of the interviews related to these subcategories of analysis can provide evidence that describe institutional power is present in the change process.

\subsection{Ontological Insecurity.}

Individuals constantly seek some level of psychological security (Schein, 1992). Insecurity generates anxiety, which can produce resistance to change in management accounting. Learning anxiety is the "feeling that is associated with the inability or unwillingness to learn something new because it appears too difficult or disruptive" (Schein, 1993, p. 86). In a study conducted by Granlund (2001), resistance to changing the accounting system arises from fear of disruption. Granlund says, "management accountants tend to resist changes to the accounting system because they are now afraid that any single change would significantly affect their workload" (2001, p. 150).

Insecurity can also manifest in other ways. Granlund (2001) demonstrates that the resistance responsible for the unsuccessful implementation of a new costing system was also promoted by fear of increasing workloads. The uncertainty resulting from anxiety must be overcome to alleviate resistance. According to Granlund (2001), the challenge is implementing policies that have been developed to improve results. When anxiety is overcome, space for a sense of psychological security emerges that allows a cognitive redefinition and the sedimentation of new practices (Busco et al., 2006). When sufficient security is achieved, maintaining repetitive behaviors and routines avoids cognitive and behavioral changes (Busco et al., 2006).

For insecurity, two subcategories, challenge and workload, were defined. The subcategory challenges is illustrated by excerpts in the text of the interviews that described a challenge, that is, the difficulty level of implementing change. The greater the difficulty of implementing a change, the greater the resulting sense of insecurity. The subcategory workload is described by excerpts of the interviews that demonstrated fear of an increased workload by those involved in the change pro- 
cess. As suggested by the theory, evidence linked to these subcategories describes the presence of the resistance factor, insecurity.

\subsection{Trust.}

Trust "is a socially constructed phenomenon. (...) trust for change is a psychological condition built in and on practices" (Busco et al., 2006, p. 32). Trust is defined as "a psychological state mediated by organizational practices - such as MAS [Management Accounting Systems] - and processes of social interaction" (Busco et al., 2006, p. 36).

For Busco, Riccaboni and Scapens (2006), trust is required to implement changes in management accounting systems. Trust in change is needed during the implementation of new management accounting systems, and accounting is needed to sustain trust in a change to practice. When disagreements occur, participation in practice facilitates reflection, and this participation may be mediated by experts and systems that leverage trust. Granlund (2001) highlights the use of consultants to provide trustworthy management accounting practices. Scapens (2006) likewise argues that trust in accounting and accounting professionals appears important for improving management accounting practices. Consequently, trust is an input that must be explored in studies of change in management accounting.

When accounting is institutionalized as a routine process, a sense of trust exists among stakeholders. In these situations, there is a trust in accounting (i.e., acceptance of accounting), and accounting and accountants are welcome to the search for solutions to a crisis. Conversely, when management accounting systems are used as ad hoc measures devoid of reliability and rationality, they are likely to be marginalized and may become sources of conflict if the organization is in crisis (Busco et al., 2006).

The use of experts and consultancy are considered ways of leveraging trust. Therefore, two subcategories were defined for the category trust, consultancy and support from experts. Busco et al. (2006) define consultancy as the actions of consulting experts that give meaning to new management practices that are being or have been implemented. For these authors, experts are specialists whose participation contributes to the use and implementation of management accounting systems. Therefore, excerpts from the interviews that describe experts or consultancy provide evidence that trust is present in the change process.

\subsection{Inertia}

Inertia is traditionally defined as the inability to make an internal change despite significant external changes (Miller \& Friesen, 1980). Inertia refers to the relative speed of organizational change in terms of responsiveness and the time required to obtain, process and evaluate environmental information (Steen, 2009).

Inertia can be understood from two types of rigidity: resource and routine. Resource rigidity arises from the external imposition of resources that are provided by an internal management action, such as the presence of technologies that excludes other technologies (Steen, 2009). The inertia resulting from routine rigidity results because routines tend to be ill suited to address discontinuity; inertia also indicates an underlying logic that permeates the mode of thinking of the organization (Steen, 2009). Therefore, when routine behaviors are challenged by new rules, the inertia of routine likely manifests through limited or incomprehensible behaviors related to change (Steen, 2009).

Routine accounting practices exhibit a certain degree of inertia, which makes changes complicated and impractical (Steen, 2009). Usual behaviors, which are the basis of rules and routines, generally exhibit some degree of resistance to change that is often attributed to inertia (Steen, 2009). Inertia comprises factors such as laziness, indolence, idleness or stoicism, about which each member of the organization has his or her own reasoning (Steen, 2009).

Inertia is directly linked to the inability of the company to react to changes imposed by the environment. If management accounting systems are understood as routines, then resistance will emerge when these routines are challenged. The delay or failure to change will be perceived as inertia and will constitute a resistance factor to the change process.

Only one subcategory was linked to this factor, stoicism. Interview evidence of the presence of this resistance factor includes manager loyalty to their own principles, indifference towards instituting changes and lack of involvement in the implementation of changes, which indicate stoicism.

\subsection{Lack of Knowledge.}

Knowledge is the maintenance of memory traces within repeated patterns of behavior and is socially developed through participation and reflection of practices rather than simply resulting from the independent thinking of individuals (Busco et al., 2006). The conventional understanding of change in management accounting is that new practices are implemented by individuals who must be trained and receive the necessary knowledge for the change to occur (Quattrone \& Hopper, 2001).

Organizations are shaped by the environment in which they operate, consisting of the myths, imposed rules, social expectations and cognitive patterns of the actors involved (Scott, 2001). Cognitive patterns that are assumed correct constitute the knowledge that is passed on to other members of the organization through training.

Granlund (2001) discusses the necessary knowledge for individuals to conduct their activities. In a study conducted by Granlund (2001), a lack of knowledge is one factor responsible for the failure to implement a costing system. According to the testimony of one project leader, at the time of implementation, the responsible team did not consider the knowledge and skills of its members, which was a factor responsible for the non-implementation of the management practice. 
The subcategory knowledge and skills was assigned to this category of analysis. Individuals who institute a change must possess the knowledge and skills that will enable its implementation. Therefore, any excerpt of the interviews that demonstrated lack of knowledge or skills by those promoting change indicated the presence of a resistance factor called lack of knowledge.

\subsection{Acceptance of routines.}

To be considered institutionalized, routines should be so widely accepted in an organization that they are considered an unquestionable form of management control (Burns \& Scapens, 2000). Granlund (2001) examines an organization that decided to implement a new costing system to cope with a financial crisis, which proved unsuccessful one year after the change commenced. Two factors behind the unsuccessful implementation of the management practice stand out: a) hiring of and quickly dismissing a group of consultants, keeping only one consultant who was elected the leader of the project, and b) not achieving acceptance of the consultant by the entire organization.

In this same study, a report prepared by the managers of the organization indicated that a major mistake made in implementing the costing system was initially excluding the accountants involved as well as the production and sales areas. This error reveals that not everyone involved in the process was convinced of the necessity of implementing the change, which led to resistance. In the words of the team responsible for implementation, this situation illustrates how a relevant idea that was accepted by senior management but not efficiently or correctly conveyed to some departments resulted in a strong resistance to the practice within the organization. The change promoted by the team leaders was not viewed as legitimate by the other managers, which also undermined the current system because no change could be implemented (Granlund, 2001).

Cobb, Helliar and Innes (1995) demonstrate that changes to the management accounting system of a bank occurred due to the effective participation of the project leader. The project leaders played a key role, managing the forces which have conduct to the change in management accounting system. The role of the leaders was to implement changes and support them before resistance was faced. The role of leaders is also highlighted by Vaivio (1999); a change to the accounting information system with the implementation of non-financial measures was supported by the initiative of the leader.

In a study conducted by Zoni, Dossi, and Morelli (2012), who explore the stages and characteristics of change in a management accounting system, the role of the leader is mentioned in one case. In the first case, supported by a survey, the authors highlight the role of the leader in driving the actions necessary to facilitate the change. The lack of leadership from the finance department may be one factor responsible for the failure of the process.

The acceptance of a change to a routine is conditioned on acceptance of the change by the other managers involved and on welcoming the leader responsible for implementing the project (as well as the performance of that leader). Two subcategories of analysis were defined for this resistance factor, welcoming of the project and acceptance of leaders. Excerpts of the interviews related to the acceptance of the project are related to these subcategories of analysis as well as to the acceptance of the project leaders by the individuals involved in the change. Thus, excerpts of the interviews related to problems in these areas indicate acceptance of routines, another factor affecting resistance.

\subsection{Decoupling or Loose Coupling.}

Decoupling is usually the result, perhaps unconscious, of an organizational choice of a technique that has not been fully implemented or of resistance to change (Dambrin et al., 2007). Loose coupling occurs when accounting practices that are introduced to meet institutional requirements are used in a ceremonial way (Scapens, 2006). Ceremonial practices occur only because they are required and do not fulfill its purpose. Thus, the procedure is not fully adopted by the agents involved (Dambrin et al., 2007).

Loose coupling denotes differences between the formal rules that aim to ensure external legitimacy and actual daily practices of the organization (Siti-Nabiha \& Scapens, 2005; Lukka, 2007; Cruz, Major, \& Scapens, 2009). Alternatively, loose coupling can be explained through its antonym, active adoption, which occurs when the implementation and internalization are completed. Implementation should consider the behavior and internalization that occur when involved individuals perceive the practice as valuable and become committed to that practice (Kostova \& Roth, 2002; Dambrin et al., 2007).

The loose coupling demonstrates resistance to a management accounting practice. From the perspective of the old institutional economics, loose coupling between rules and routines occurs when the routine is not performed in accordance with the rules. A subcategory of analysis, unfollowed procedures, was assigned to this resistance factor. Excerpts of the interviews that describe total or partial noncompliance of procedures due to a change in the management system would indicate the presence of this resistance factor.

\section{METHODOLOGICAL PROCEDURES}

Two cases were selected for the study, Company A and Company B, which possess some extreme charac- teristics that differentiate them and thus enrich the results (Yin, 2010). For example, Company A failed to 
implement an integrated management system, while Company B was able to implement an integrated management system. Company A has been operating for nearly a century, while Company B has been operating for approximately a decade.

The use of extreme cases produces more knowledge from the observed phenomena, enriched by variation in the categories of analysis (Cooper \& Morgan, 2008). Cases exhibiting contrasting situations and findings increase external validity (Yin, 2010). These companies were also selected because the authors had access to the organizations (Eisenhardt, 1989; Tessier \& Otley, 2012) and were aware that companies had undergone or were undergoing changes to their management accounting systems that involved the adoption of integrated management systems.

To elaborate the design of the study, it was necessary to identify the categories and subcategories of analysis. The design of the study guides the preparation of the interviews and questionnaires, which must be supported by triangulation with other techniques, such as observation and document analysis (Eisenhardt, 1989). The identification of the categories and subcategories of analysis was performed by coding. Coding "involves identifying and recording one or more passages of text or other data items such as the parts of pictures that, in some sense, exemplify the same theoretical or descriptive idea" (Gibbs, 2009, p $60)$. The study design is presented in Table 1.

Table 1

Study Design

\begin{tabular}{|c|c|c|c|}
\hline Objective & Category & Subcategories & Authors \\
\hline \multirow{12}{*}{$\begin{array}{l}\text { To analyze the factors affecting resistance that } \\
\text { are present during the process of implementing } \\
\text { an integrated management system from the pers- } \\
\text { pective of institutional theory grounded in the old } \\
\text { institutional economics }\end{array}$} & \multirow[t]{3}{*}{ Institutional power } & Autonomy of departments & Scapens and Roberts (1993) \\
\hline & & Advantages of delegation & Scapens and Roberts (1993) \\
\hline & & Advantages of performance & Scapens and Roberts (1993) \\
\hline & \multirow[t]{2}{*}{ Insecurity } & Challenge & Granlund (2001) \\
\hline & & Workload & Granlund (2001) \\
\hline & \multirow[t]{2}{*}{ Trust } & Consultancy & Busco, Riccaboni, and Scapens (2006) \\
\hline & & Experts & Busco, Riccaboni, and Scapens (2006) \\
\hline & Inertia & Stoicism & $\begin{array}{l}\text { Miller and Friesen (1980) } \\
\text { Steen (2009) }\end{array}$ \\
\hline & Lack of knowledge & Knowledge and skills & Granlund (2001) \\
\hline & \multirow[t]{2}{*}{ Acceptance of routines } & Welcoming of the project & $\begin{array}{l}\text { Burns and Scapens (2000) } \\
\text { Granlund (2001) }\end{array}$ \\
\hline & & Acceptance of leaders & Granlund (2001) \\
\hline & Decoupling & Unfollowed procedures & Dambrin, Lambert, and Sponem (2007) \\
\hline
\end{tabular}

Table 1 shows the design of the study, which includes the objective and is related categories and subcategories. To achieve this objective, evidence from the surveyed companies regarding the categories and subcategories must be observed. Each category and subcategory listed was obtained from the corresponding study listed in the final column.

The data were collected using semi-structured interviews. The management level managers for both companies were interviewed. Management level managers are those responsible for the areas of accounting/controllership, finance, human resources, sales, foreign trade, production, engineering, quality control, research and development, information technology and administration. The majority of managers interviewed experienced the period of change in the management accounting system. However, in Company A, of the nine managers interviewed, two only partially experienced the change process and two were hired after the change. At Company $\mathrm{B}$, of the seven managers interviewed, only one was hired after the change. All managers were interviewed because even when managers did not actively participate in the process, they could contribute to descriptions of the socio-institutional context, issues related to knowledge and skills necessary to operate the ERP system, participation level of managers in decisions and power relations. The director(s) of the organization were also interviewed because his or her contributions would enrich the data, especially the history of the organization and the management accounting change process.

Consistent with the research recommendation for a case-study approach, a company was selected for a pilot case study (Yin, 2010). The main concern was to establish whether the interview script was properly structured to obtain responses that could be analyzed and classified into the categories of analysis. The results of the pilot case study revealed that the interview script was appropriate to the research objectives.

To ensure data reliability, the interviews were recorded with respondent permission. Sixteen interviews were conducted for the two companies, totaling approximately nine hours of recordings. The interviews were conducted during the months of March, April and May 2012. Table 2 displays the managers interviewed in each company and the length of each interview. 
Table 2

Surveyed areas and interview length

\begin{tabular}{lcc}
\hline Interviewed Areas & \multicolumn{2}{c}{ Recorded interview length (minutes) } \\
\cline { 2 - 3 } & Company A & Company B \\
\hline Accounting & 54 & 35 \\
\hline Engineering & 31 & - \\
\hline Research and Development & 12 & - \\
\hline Sales & 34 & 12 \\
\hline Human Resources & 28 & 17 \\
\hline Foreign Trade & 31 & - \\
\hline Production & 31 & 21 \\
\hline Finance & 37 & 21 \\
\hline Board of Directors & 40 & 65 \\
\hline Information Technology & - & 32 \\
\hline Total & 298 & 203 \\
\hline
\end{tabular}

The interviews were then transcribed and presented to the interviewee for validation. After validation, con- tent analysis was applied (Bardin, 1997). All interviews were carefully analyzed, and excerpts related to the categories and subcategories of analysis were highlighted. According to Gibbs (2009), all the excerpts identified in the written text that relate to the same topic should be classified with the same code (category of analysis).

Based on the categories and subcategories of analysis, each case was analyzed to reveal the patterns derived from each situation. At this stage, connections were made among the data collected through interviews, documents (Excel spreadsheets, internally circulated notices, regional newspaper articles), unstructured interviews of operations personnel, suppliers and consultants who assisted the implementation of the systems to triangulate the data and ensure validity and consistency in the analysis. Finally, for each category of analysis, a chart was prepared matching the excerpts to each subcategory of analysis.

\section{PRESENTATION OF THE CASES AND ANALYSIS OF RESULTS}

Two companies were selected for this study. At the request of the companies, and as established in the case study protocol, their identities will not be revealed. However, to contextualize the study, some information about the organizations is listed in Table 3.

Table 3

Characteristics of the companies selected for the study

\begin{tabular}{|c|c|c|}
\hline Description & Company A & Company B \\
\hline National market & $\begin{array}{l}\text { Operates throughout } \\
\text { the country }\end{array}$ & $\begin{array}{c}\text { Operates } \\
\text { throughout the } \\
\text { country }\end{array}$ \\
\hline International market & $\begin{array}{c}\text { Central America, } \\
\text { Africa, South America }\end{array}$ & Europe, Asia \\
\hline Type of corporation & Stock corporation & Stock corporation \\
\hline Length of operation & $\begin{array}{l}\text { Approximately one } \\
\text { century }\end{array}$ & $\begin{array}{c}\text { Approximately one } \\
\text { decade }\end{array}$ \\
\hline Annual Revenues & Not revealed & $\begin{array}{l}\text { Approximately } 1 \\
\text { billion }\end{array}$ \\
\hline Field & Health & $\begin{array}{l}\text { Oil, Gas and } \\
\text { Biofuels }\end{array}$ \\
\hline Capital & $\begin{array}{l}\text { Closely held - } \\
\text { National }\end{array}$ & $\begin{array}{l}\text { Closely held - } \\
\text { National }\end{array}$ \\
\hline $\begin{array}{l}\text { Integrated management } \\
\text { system }\end{array}$ & Not implemented & Implemented \\
\hline
\end{tabular}

Table 3 provides an overview of the companies that were surveyed in preparation for this study. Some information is not disclosed because authorization for disclosure by the companies was not obtained. Regardless, the selected companies possess the capacity to meet national and international market demands. Each company operates in a specific industry. The length of operation differs significantly between the organizations. The implementation of integrated management system was not accomplished in Company $\mathrm{A}$ and was accomplished in
Company B. The characteristics provided in Table 3 indicate that the cases have extreme characteristics, which are suitable for enriching the research findings (Scapens, 1990, Yin, 2010).

After describing the cases, the context of each company is presented below.

\subsection{Analysis of Results for Company A.}

This study addresses the seven factors that affect resistance to change, which are gathered from the existing research on the subject and are described in section 2 .

Company $\mathrm{A}$ is an important case because a project to implement an integrated management system was discontinued. Of the seven proposed resistance factors, evidence for the following six factors was observed in the interviews: insecurity, trust, inertia, knowledge, acceptance of routines and decoupling. Of these factors, trust was particularly relevant and is linked to support for external consultants and internal experts to assist in the implementation of the new management system. The evidence suggests that the company appointed and trained a person to assist in the implementation of the integrated management process. However, the consultancy offered by the supplier of the integrated management system was not equipped for such a task, which effectively contributed to the non-implementation of the system.

The supplier was therefore unable to gain the trust of the managers that the system would truly meet the requirements of the company, which has been agreed upon during the negotiation of the purchase. Some excerpts indicate a lack trust. For example, Manager 3 highlights that the implementation of the accounting module was performed by experts in information technology who did not have expertise in accounting and tax. According to Manager 3, “...the IT staff came to implement an accoun- 
ting system without knowing anything about tax, debit, credit". Manager 8 also states that the human resources module lacked the support of consultants who were experts in that field. Those responsible for implementing the integrated management had no knowledge of the operations of the industry. According to Manager 8:

(...) The people who were there were not prepared. I believe that when a consulting firm implements an ERP system within a company, let's suppose in the HR field, the firm must send an HR consultant, a person who understands the laws, who understands the rules, who understands what he or she is going to implement there. The people who came to provide consultancy were not prepared to provide the support that we need in HR.

The reports indicate that the consultancy service was inadequate because the consultants were not adequately trained to assist in implementing the system. The subcategory consultancy revealed that this environment did not generate the psychological condition of trust, and this category contributed to resistance to the implementation of the integrated management system.

The analysis of Company A reveals that some factors are more important to resistance. Here, trust stands out. Change in a management accounting system differs by organization, a differentiation that is not characterized only by the observed factors of resistance. In addition, in this case, the change process involved varying intensity for each resistance factor. Therefore, there is a particular intensity level for each factor, which is unique to each organization. Regardless of the change process, this variation differentiates the change process and makes it unique. In some organizations, trust is the factor that most influenced resistance. In other organizations, other resistance factors may prevail. Resistance processes are unlikely to exhibit the same configuration in either the same company or a different company.

The environment in which a change is proposed is also notable and should be favorable to the change. During the implementation project of the new integrated management system, Company A underwent a significant change in its operational processes as required by regulatory agencies, which involve transitioning from being managed by partners to being managed by professionals hired for those positions. This indicates that the company was adapting to environmental contingencies. A similar situation occurs in Vaivio's (1999) study in which the implementation of non-financial management measures was relegated to the background when other issues were deemed more urgent during a merger. The management process of non-financial measures resumed in an environment that appeared uncertain and competitive, forcing managers to seek an expansion in the control system of the company.

The phenomenon as well as the fact that the implementation project was discontinued can also be analyzed using other theories, such as contingency theory. When the environment is unfavorable to change, change does not occur. Therefore, the environment can be a factor affecting resistance to changing management accounting systems. Reality can be observed from various angles to produce different understandings according to the objectives of each study.

\subsection{Analysis of Results for Company B.}

The importance of resistance arising from a change process should not be underestimated. Resistance can reach a level that prevents change in management accounting. Resistance occurs in any change process, but understanding how it manifests helps explain the phenomenon.

The categories that indicate resistance were identified during the survey. The new integrated management system was implemented in the company and is being used normally. The resistance factors, although present, were not sufficiently strong to derail the change process. Insecurity and decoupling were the foci of resistance. The evidence collected by the survey indicates clearly the change process was challenging. During the process, expectations for the new system as well as for the changes that might be required to execute some functions were established. The evidence also indicates that managers felt that workloads would increase due to the change in the management accounting system.

Through the testimonials of Managers 4 and 7, expectations for the operation of the new system were revealed. According to Manager 7, “(...) resistance occurs even when one is included the project, the fear, the uncertainty of whether it will work; whether this change will do good”. Likewise, Manager 4 notes, “(...) everyone gets a bit distressed because many companies comment that the system (system name) considerably restricts the way the company operates".

Because the company already had a system in place, expectations were created by those involved about the probability of the new system successfully replacing the old one. Managers 3, 4 and 5 describe the period of change as a period of overload. Current routines should be maintained while the same person is involved in implementing the new system. Thus, replacing the integrated management process generated an atmosphere of stress, resulting from the deadlines for implementation and expectations for operation and success.

This stress, and part of the resistance, was attributed to fear that the new system could replace tasks that were being performed manually by employees. According to Managers 7 and 5, some employees feared that the new system might eventually replace them. Manager 5 notes, "...in the beginning, the staff was afraid that it would reduce the number of employees". However, this fear was not realized in this company. According to the testimonials, some human functions were actually displaced with the implementation of the system, but because the company already possessed a lean workforce, individuals who performed these functions were even- 
tually reallocated to other activities, thus avoiding any dismissals.

Thus, this complex process created challenges for the management department. Nevertheless, expectations always form when changes to management accounting systems occur. These expectations can become foci of resistance. Therefore, resistance to a change process should not be disregarded. Without strategies to mitigate resistance, change processes can fail, compromising the resources and continuity of the organization.

The insecurity identified in the workload subcategory among many managers indicates concern regarding the additional effort that implementation of the new integrated management system would require. An integrated system had already been implemented in the organization, and migrating from the current system to another generated expectations for increased workloads. The testimony of Manager 3 indicates that in the beginning, additional hires resulted from the project. During the implementation of the new integrated management system, the department of information technology was established, which was assigned the coordination of activities involved in replacing the existing system. According to Manager 3, “(...) what we knew is that at first, there would be even an increase in manpower. And indeed there was".

Increased workloads change individuals' daily routines. These changes can provoke insecurity, which is a resistance factor. The evidence indicates that a considerable portion of the resistance to the implementation of a new integrated management process resulted from ontological insecurity. Nevertheless, the resistance arising from such insecurity was not sufficient to prevent the implementation of the new management practice.

Resistance was more latent in the decoupling category. According to the testimonials of the managers, at the beginning of the process, the new procedures were not followed readily. The old procedures to which managers were accustomed prevailed at the expense of the new procedure, which required individuals to leave the comfort of old routines and replace them with new, hitherto unknown routines. Manager 5 mentions that there was initial resistance, as expected, to the new integrated management system processes. According to Manager 5, “(...) it is natural that people are accustomed to their spreadsheets and do it daily, and this is a bit automatic, is in the brain. (...) However, today the greatest resistance is in habit".

This resistance is linked to individuals who proceed habitually in a particular way and are subsequently required to act in a new, unknown and different way. At that time, employees knew that a procedure had to be modified or replaced. This factor also appears in the statements of Manager 7, who mentions that some employees were used to working in Excel and, at first, did not want to use the new system. According to Manager 7, “(...) it is difficult mainly because the staff is used to using Excel and do not want to use the system". Therefo- re, the new procedure was not being followed.

However, neither individual resistance factors nor their combination was sufficient to stop the change in the management accounting system. According to the managers, success was credited to the short length of operation of the company, which implies that the staff members involved in the project had been recently hired. The managers believed that employees with short tenures in the organization could not establish routines set enough to offer strong resistance. Additionally, the respondents believed that because of the short history of the company, the managers had retained an entrepreneurial spirit and were more sympathetic to efforts that would allow different projects, including changes to the management accounting systems, to achieve their goals.

Other sources of resistance were attenuated by a strategy adopted by the board of directors. The extensive use of consultants and hiring a leader with experience and knowledge created trust among those involved in the change process. The existence of trust during the management process is critical to eliminate foci of resistance. Another source of resistance observed during the implementation of the new integrated management system was the acceptance of routines.

The care taken by the board of directors to provide sufficient information to clarify the change process for everyone involved, including the public, created a friendly, welcoming environment for changing the management accounting system. The experience of management-level staff obtained from previous experiences and training was identified as a factor that mitigated a potential source of resistance.

Other resistance factors such as ontological insecurity and acceptance of routines were not sufficiently strong to prevent the implementation of the new system. Sources of resistance remained, especially a lack of knowledge and skills at the operational level.

According to the managers, efforts to endow the operational level with adequate knowledge and attitudes towards the new management system are required to extract all possible benefits from the system because resistance continues even after a change is implemented. The institution of an integrated management system does not necessarily eliminate all resistance factors. Therefore, the institutionalization of management accounting systems may evolve over time until all foci of resistance return to a latent stage. This factor varies from company to company and from situation to situation.

\subsection{Analysis and Discussion of Resistance Factors During the Change Process.}

Resistance factors cannot be relegated to a background or regarded as irrational factors in the change process. Studies have observed the presence of resistance factors during changes in management accounting practices (Scapens \& Roberts, 1993; Granlund, 2001). Table 4 indicates that each company exhibited a set of specific resistance factors that originated internally. 
Table 4

Factors affecting resistance to changing management accounting systems

\begin{tabular}{lcc}
\hline Resistance factors & Company A & Company B \\
\hline Institutional power & No & No \\
\hline Ontological insecurity & Yes & Yes \\
\hline Trust & Yes & Yes \\
\hline Inertia & Yes & No \\
\hline Knowledge & Yes & Yes \\
\hline Acceptance of routines & Yes & Yes \\
\hline Decoupling & Yes & Yes \\
\hline
\end{tabular}

The purpose of Table 4 is not comparison but to highlight which resistance factors were identified in Company A and Company B. Table 4 does not imply that this change did not occur in Company A because it exhibited more resistance factors than Company B did.

The first attempt Company A made to implement an integrated management system was unsuccessful. Six categories of resistance were identified. Although trust was stronger than the other factors, this does not imply that trust was solely responsible for the non-implementation of the integrated management system.

All sources of resistance contributed, but trust is particularly relevant to Company A because of the intensity of the evidence collected. The role of experts is essential to ensure trust in the process and to reduce uncertainty (Busco et al., 2007). The use of consultants helps reduce uncertainty during the change process. Consultants endow the new management practices with rationality and prevent them from being marginalized, fomenting conflict in the organization (Busco et al., 2006).

In Company A, the consultancy offered by the supplier of the system was not sufficient to mitigate the uncertainty present in the change or provide trust in those involved in the project. This factor, combined with the other factors, constituted sufficient resistance to the implementation of the new system of management control that the implementation process was derailed.

A study conducted by Jermias (2006) highlights the trust individuals have in the systems they adopt. Trust in the adopted systems contributes to their institutionalization. The greater the trust, the lower the resistance to change. Trust is supported by expert consultants and professionals, which is mentioned in the study conducted by Busco et al. (2006).

Zoni et al. (2012) address the issue of trust during a change in management accounting system. In this case, trust in the process was generated by a group of experts in information technology.

In Company B, the new integrated management system was implemented because the resistance factors were not sufficiently strong to stop the process. During the change process, two resistance factors operated with more intensity: insecurity and decoupling or loose coupling. Insecurity is common during change in management accounting systems (Granlund, 2001). Managers worry about the effectiveness of the new management system because it will change the way they do their work (Granlund, 2001).

Busco et al. (2006) argue that the moment that managers adopt routine behaviors is a sign that an atmosphere of security has been created. When transition to a new management system begins, that atmosphere of security is broken; that insecurity constitutes a source of resistance. At Company B, insecurity was present during the entire transition to the new management control system until managers noticed that the new integrated management system actually functioned and met company needs.

Decoupling or loose coupling was a resistance factor observed in Company B. At the beginning of the process, the old procedures prevailed over the new procedures. Managers maintained their routine controls at the expense of the new procedures that were required by the new integrated management system. Decoupling occurred where the preferences of managers maintained management previous practices (Dambrin et al., 2007; Steen, 2011).

Decoupling is a process that must be understood as an internal resistance factor (Siti-Nabiha \& Scapens, 2005). Decoupling will not always be present because of external factors, as advocated by the new institutional sociology. In a study conducted by Dambrin, Lambert, and Sponem (2007), decoupling occurs and is understood as a form of resistance to change, which stems from disagreements among the organizational discourse, new ideals and control techniques.

The resistance factors identified in the surveyed companies also appear in other studies. In a study conducted by Guerreiro, Frezatti, Lopes and Pereira (2005), changes in management accounting systems must overcome obstacles, such as individual insecurity. They attribute the low level of practical implementation of changes in management accounting systems to the misalignment of individual expectations and disagreement with the social norms of behavior institutionalized in the organization. The factors cited by Guerrero et al. (2005) may be related to the categories of acceptance of routines and insecurity used in this study.

Resistance factors related to change process in the management accounting system were found in the study by Vicente Pinto, and Major (2011). In addition to identifying a conservative corporate culture as an inhibitory factor of change, the authors also noted the factor inherent to the adaptation to new technologies. Adapting to new technologies involves the need for new knowledge. Moreover, adaptation to new technologies can create insecurity in those affected. Therefore, the results of the study conducted by Vincente et al. (2011) are somewhat consistent with the results found in this study.

One context that merits further discussion involves Company B. In Company B, the old integrated management system was replaced by a new system. However, this does not imply that all resistance factors to the change process were overcome. Some resistance factors are still prevalent and require mitigation, such as a persistent lack of knowledge. 
According to the testimonials, although the staff is well prepared, there is still a lack of investment in training at the operational level in terms of knowledge and attitude towards the new management system. The respondents note that this must be overcome so that the organization can fully enjoy all the benefits that the new system offers. By analyzing change in management accounting systems from this perspective, it is concluded that the change process does not end when a new system is implemented.

In the mentioned case, the change process is considered to be incomplete and to lack actions that will lead the organization to a more efficient and effective use of the new instrument. Insecurity regarding the benefits that the new instrument will provide to the organization remains in the environment. Doubts regarding the gain that the organization has obtained or will obtain with the implementation of change can only be resolved with time, and even then, without an objective measurement.

The change process is thought to involve a peak in which the resistance factors exhibit the greatest intensity. If the resistance factors do not reveal enough strength to stop the change process at this peak, then the change will be implemented. However, the fact that the resistance factors lose strength does not mean they are fully eliminated. Resistance factors are always present in the organization; however, they will be in a state of latency for most of the time.

Resistance factors make up the socio-institutional context of organizations. The beginning of the change process constitutes the trigger that wakens the resistance factors, which increase their intensity as the change process advances. In some cases, the intensity of the resistance factors is such that it eventually stops the change process.

This situation occurred in company A. From the moment the process of implementing the integrated management system was discontinued, resistance factors began to lose intensity, going back to an early stage of latency. In this case, the resistance factors were not eliminated; they remain in the socio-institutional context of the company. Certainly, they will manifest again in another attempt to implement an integrated management system.

In the case of the company $\mathrm{B}$, resistance factors also manifested but not necessarily with the same intensity as in company A. The resistance factors in company B did not prevent the implementation of the new integrated management system, and by no means been eliminated. There was a point at which the resistance factors reached a maximum intensity but were not sufficient to discontinue the implementation process.

Over time, these factors began to lose strength and intensity, returning to the original state. In such a case, these factors are not considered to have been eliminated. They only tend to return to a state of latency until a new change process in management accounting syste$\mathrm{ms}$ is established. Therefore, these resistance factors are part of the socio-institutional context and are rooted in human nature, which is outside the purview of an economic-rational perspective.

Resistance factors rooted in human nature are mentioned by authors such as Lawrence (1954), Seo and Creed (2002) and Steen (2011). Lawrence (1954) relates resistance to human action, stating that the individuals manifest resistance when they realize that social changes can occur due to technical changes. According to Seo and Creed (2002), change emerges from contradiction; however, these contradictions can only be mediated by human praxis. Thus, if resistance is inherent to change, then there is an interdependent relationship between resistance and human praxis. Human praxis operationalizes resistance factors. Zoni et al. (2012) note that resistance to change stems from many elements that involve the intention to promote change. In addition, they emphasize that the actions of key individuals throughout the change process is essential for institutionalizing the change. This approach, offered by the authors, highlights human involvement during the change process.

The changes to management accounting systems replace routines (Burns \& Scapens, 2000). Routines stem from the actions of multiple actors in the organization (Steen, 2011). The change process challenges pre-existing routines and consequently provokes resistance (Scapens \& Roberts, 1993). Therefore, these positions also contribute to the understanding that resistance lies in the set of beliefs and values instilled in the individual by the social system in which he or she is embedded.

For each company, a different set of resistance factors was identified. In Company A, of the seven resistance factors proposed, six were identified (i.e., all except institutional power). In Company B, of the seven resistance factors proposed, five factors were identified (i.e., all except institutional power and inertia). In both companies, some resistance factors exhibited greater relevance or intensity. The intensity of each factor was measured by the number of interview excerpts were related to those factors. Some factors, such as trust in Company A, were related to many different excerpts. Conversely, other factors were not related to as many excerpts.

This evidence suggests that each company possesses a specific set of resistance factors. In each set, individual resistance factors exhibit particular intensities. For instance, in some companies, resistance factors related to decoupling and insecurity might prevail. In others, the acceptance of routines might prevail. The combination that comprises the set of factors and the intensity of each factor in each organization will tend to be unique for each company analyzed.

Therefore, the analysis of the factors contributing to resistance indicates that they play an important role in the change process of management accounting systems. In Company A, these resistance factors discontinued the change process, which compromised company resources, led to weariness among managers and wasted the spent time on the project. There was no improvement because the change did not occur. 
Understanding the factors that affect resistance during a change to management accounting systems maximizes the likelihood that organizations succeed in implementing the change. Therefore, the results of this analysis confirm the study hypothesis that a change in management accounting systems through the implementation of an integrated management system faces a particular set of factors representing internal resistances in the organization, and each factor varies in intensity and is permanently present in the company.

\section{CONCLUSION}

Resistance to change in management accounting system cannot be ignored. In Company A, resistance manifested during the implementation of an integrated management system and was strong enough to disrupt the change process. In Company B, an integrated management system was implemented, and in this case, resistance to the process occurred but was not strong enough to disrupt it.

In this study, resistance to change was analyzed based on seven factors. The results indicate that factors affecting resistance start to counteract change in the moment that the process begins. These resistance factors reside in human nature and are permanently present in the socio-institutional context of organizations, even if in a latent state. Several resistance factors emerge during the change process, but some are more intense than others. Resistance factors will not always be strong enough to prevent change. In addition, the efforts of management to mitigate the resistance factors during the change process can maximize the probability of successfully implementing a change.

The study hypothesis was tested using evidence collected from Company A and Company B. The only resistance factor for which no evidence was observed was institutional power. Replicating this study in other contexts is recommended. As demonstrated in this stu$d y$, each change process is affected by a particular set of resistance factors that vary in intensity. Therefore, that factors that were not identified in this study, such as institutional power, might appear in other situations. Some resistance factors were supported by more evidence than others were, indicating that some factors are more intensity than others are.

In this study, the resistance factors are triggered when the change process begins, and the may prevent change if they gather enough strength. If the force exerted by the resistance factors is not sufficient to disrupt the change process, change will occur and the resistance factors will to return to their original state (latency) over time. Therefore, regardless of successful change, the resistance factors are not eliminated but return to a latent state until a new change process begins.

Finally, the important role of a company's board members in mitigating resistance to change must be noted. The successful implementation of an integrated management system in Company B stems from the strategies employed to mitigate resistance. In this study, resistance is rooted in human nature; therefore, resistance to any change process in management accounting will always occur. Because this study is limited to the two cases described, future research is recommended to assess whether resistance is always present in the change process. Future research should replicate this study for other companies to identify other resistance factors that may arise during a change in management accounting systems.

\section{References}

Bardin, L. (1997). Análise de conteúdo. Lisboa: Edições 70.

Bryman, A. (1984). Organization studies and the concept of rationality. Journal of Management Studies, 21 (4), 391-408.

Burns, J., \& Scapens, R. W. (2000). Conceptualizing management accounting change: an institutional framework. Management Accounting Research, 11 (1), 3-25.

Burns, J., \& Vaivio, J. (2001). Management accounting change. Management Accounting Research, 12 (4), 389-402.

Busco, C., Quattrone, P., \& Riccaboni, A. (2007). Management accounting issues in interpreting its nature and change. Management Accounting Research, 18 (2), 125-149.

Busco, C., Riccaboni, A.; \& Scapens, R. W. (2006). Trust for accounting and accounting for trust. Management Accounting Research, 17 (1), 11-41.

Carruthers, B. G. (1995). Accounting, ambiguity, and the new institutionalism. Accounting, Organizations and Society, 20 (4), 313-328.

Coob, I., Helliar, C., \& Innes, J. (1995). Management accounting change in a bank. Management Accounting Research, 6 (2), 155-175.

Cooper, D., \& Morgan, W. (2008). Case study research in accounting. Accounting Horizons, 2 (22), 159-178.
Cruz, I., Major, I., \& Scapens, R. W. (2009). Institutionalization and practice variation in the management control of a global/local setting. Accounting, Auditing \& Accountability Journal, 22 (1), 91-117.

Dambrin, C., Lambert, C., \& Sponem, S. (2007). Control and change analyzing the process of institutionalization. Management Accounting Research, 18 (2), 172-208.

Dechow, N., Granlund, M., \& Mouritsen, J. (2007). Management control of the complex organization: relationships between management accounting and information technology. In C. S. Chapman, A. G. Hopwood, \& M. D. Shields. (Orgs.). Handbook of Management Accounting Research. (Vol. 2). Oxford, UK: Elsevier.

Dermer, J. D., \& Lucas, R. G. (1986). The illusion of managerial control. Accounting, Organizations and Society, 11 (6), 471-482.

Eisenhardt, K. M. (1989). Building theories from case study research. The Academy of Management Review, 14 (4), 532-550.

Ferreira, A., \& Otley, D. (2009). The design and use of performance management systems: an extended framework for analysis. Management Accounting Research, 20 (4), 263-282. 
Gibbs, G. Análise de dados qualitativos. Porto Alegre: Artmed, 2009.

Granlund, M. (2001). Towards explaining stability in and around management accounting systems. Management Accounting Research, $12(2), 141-166$

Granlund, M., \& Mouritsen, J. (2003). Introduction: problematizing the relationship between management control and information technology. European Accounting Review, 12 (1), 77-83.

Guerreiro, R., Frezatti,'F., Lopes, A. B., \& Pereira, C. A. (2005). O entendimento da contabilidade gerencial sob a ótica da teoria institucional. Organizações \& Sociedade, 12 (35), 91-105.

Jeacle, I. (2003). Accounting and the construction of the standard body. Accounting Organization e Society, 28 (4), 357-377.

Jermias, J. (2006). The influence of accountability on overconfidence and resistance to change: a research framework and experimental evidence. Management Accounting Research, 17 (4), 370-388.

Kostova, T., \& Roth, K. (2002). Adoption of an organizational practice by subsidiaries of multinational corporations: institutional and relationa effects. Academy of Management Journal, 45 (1), 215-233.

Lawrence, P. R. (1954). How to deal with resistance to change. Harvard Business Review, 32 (3), 49-57.

Lukka, K. (2007). Management accounting change and stability: loosely coupled rules and routines in action. Management Accounting Research, 18.(1), 76-101.

Major, M., \& Hopper, T. (2005): Managers divided: implementing ABC in a Portuguese telecommunications company. Management Accounting Research, 16 (2), 205-229.

Malmi, T. (1997). Towards explaining activity based costing failure: accounting and control in a decentralized organization. Management Accounting Research, 8 (4), 459-480.

Miller, D., \& Friesen, P. H. (1980). Momentum and revolution in organizational adaptation. Academy of Management Journal, 23 (4), 591-614.

Moll, J., Burns, J., \& Major, M. (2006). Institutional Theory. In Z. Hoque. (Ed.). Methodological issues in accounting research: theories, methods and issues. London: Siramus.

Napier, C. J. (2006). Accounts of change: 30 years of historical accounting research. Accounting, Organizations and Society, 31 (4-5), 445-507.

Otley, D. T. (1999): Performance management: a framework for management control systems research. Management Accounting. Research, 10 (4), 363-382.

Quattrone, P., \& Hopper, T. (2001). What does organizational change mean? Speculations on a taken for granted category. Management Accounting Research, 12 (4), 403-435.

Ribeiro, J. A., \& Scapens, R. W. (2006). Institutional theories in management accounting change: contributions, issues and paths for development. Qualitative Research in Accounting \& Management, 3 (2), 94-111.

Scapens, R. W. (1990). Researching management accounting practice: the role of case study methods. British Accounting Review, 22 (3), 259-281.

Scapens, R. W. (1994). Never mind the gap: towards an institutional perspective on management accounting practice: Management Accounting Research, 5 (3/4), 301-321.

Scapens, R. W. (2006). Understanding management accounting practices: a personal journey. The British Accounting Review, 38 (1), 1-30.

Scapens, R., \& Jazayeri, M. (2003). ERP systems and management accounting change: opportunities or impacts? A research note. European Accounting Review, 12 (1), 201-233.

Scapens, R. W., \& Roberts, J. (1993). Accounting and control: a case study of resistance to accounting change. Management Accounting Research, $4(1), 1-32$

Schein, E. H. (1992). Organizational culture and leadership. Jossey-Bass Publishers: San Francisco.

Schein, E. H. (1993). How can organizations learn faster? The challenge of entering the Green Room. Sloan Manage Review, 34 (2), 85-92.

Scott, W. R. (2001). Institutions and organizations. Thousand Oaks, CA: Sage.

Seo, M., \& Creed, D. W. E. (2002). Institutional contradictions, praxis, and institutional change: a dialectical perspective: The Academy of Management Review, 27 (2), 222-247.

Siti-Nabiha, A. K., \& Scapens, R. W. (2005). Stability and change: an institutionalism study of management accounting change. Accounting, Auditing and Accountability Journal, 18 (1), 44-73.

Steen, M. V. D. (2009). Inertia and management accounting change: the role of ambiguity and contradiction between formal rules and routines. Accounting, Auditing \& Accountability Journal, 22 (5), 736-761.

Steen, M. V. D. (2011). The emergence and change of management accounting routines. Accounting, Auditing \& Accountability Journal, 24 (1), 502-547.

Tessier, S., \& Otley, D. (2012). From management controls to the management of controls. Accounting, Auditing \& Accountability Journal, 25 (5), 1-33.

Vaivio, J. (1999). Exploring a non-financial management change. Management Accounting Research, 10 (4), 409-437.

Vicente, C. C. S., Pinto, J. C. C., \& Major, M. J. (2011). Mudanças nas práticas de controlo de gestão em Portugal. Contabilidade \& Gestão OTOC, 10 (1), 9-40.

Wagner, E. L., Moll, J., \& Newell, S. (2011). Accounting logics, reconfiguration of ERP systems and the emergence of new accounting practices: a sociomaterial perspective. Management Accounting Research, 22 (3), 181-197.

Weick, K. E. (1976). Educational organization as a loosely coupled system. Administrative Science Quarterly, 21 (1), 1-19.

Yin, R. K. (2010). Estudo de caso: planejamento e métodos. Porto Alegre: Bookman.

Zoni, L., Dossi, A., \& Morelli, M. (2012). Management accounting system (MAS) change: field evidence. Asia-Pacific Journal of Accounting \& Economics, 19 (1); 119-138. 
